\title{
NECTAR AND POLLEN PRODUCTIVITY OF COMMON CHICORY
}

\section{Adamchuk Leonora ${ }^{1 *}$, Bilotserkivets Tetiana², Šimková Jana ${ }^{3}$}

\author{
${ }^{1}$ National University of Life and Environmental Sciences of Ukraine, Kyiv, Ukraine \\ ${ }^{2}$ Ukrainian Laboratory of Quality and Safety of Products of the Agro-Industrial Complex, Chabany, Ukraine \\ ${ }^{3}$ Institute of Biodiversity Conservation and Biosafety, Slovak University of Agriculture in Nitra, Slovak Republic
}

There is a need for further study of new and forgotten species of high-yielding plants for the expansion of biodiversity of the forage base of honey bees and the receipt of high-quality commercial products at bee-farms. The aim of research was to explore pollen and honey properties of common chicory (Cichorium intybus L.). The selection of plant samples was carried out in Kyiv, Vinnytsia, Khmelnytsky, Poltava, Sumy, Chernihiv and Kirovohrad regions of Ukraine. Standard statistic and morphometric methods, as well as mathematical formulas were used for determining the biological performance indicators. A long flowering period of common chicory was ascertained in the range from 75 to 102 days. Plant productivity indicators for honey bees were established. Biological nectar productivity was in the range from 92.55 to $190.04 \mathrm{~g}$ from one common chicory plant. Honey productivity was in the range from 166.59 to $301.34 \mathrm{~kg} / \mathrm{ha}$. The biological pollen productivity of one plant of common chicory was in the range from 1.785 to $3.064 \mathrm{~g}$. As a result of pollen analysis of polyfloral honey obtained during the summer of 2016 the pollen grains of common chicory were found in the range from 1 to $27 \%$. Pollen lumps of common chicory in the range from 10 to $80 \%$ of the total fee were in polyfloral bee pollen collected during the summer of 2016 . The morphometric parameters of the bee pollen were ascertained: the sharping level of the pollen lump was $4 \pm 0.15$ points, the weight of one pollen lump was $7.21 \pm 0.255 \mathrm{mg}$, the length of one pollen lump was $3.42 \pm 0.048 \mathrm{~mm}$, the width of one pollen lump was $2.97 \pm 0.070 \mathrm{~mm}$. Our further research in this direction may be conducted to determinate of the biologically active components of cichorium honey and bee pollen.

Keywords: nectar; honey; pollen productivity; Cichorium

\section{Introduction}

Recently, scientists devote much attention to providing of bees with high quality feed (Максимов et al., 2014; Рожков и Токар, 2014). Scientists point to the necessity to optimize forage resources for bees and improve honey-pollen resources of the area (Brovarskij et al., 2010; Боярчук 2015; Люльчак і Адамчук, 2016). For this purpose, special honey plants are used, which are grown specifically for bees, on the grounds of their high productivity, valuable medicinal or commodity qualities of the products obtained from them and prolonged use (Глухов, 1955; Brovarskij et al., 2010; Brindza et al., 2015; Grygorieva et al., 2016; Адамчук та ін., 2016; Redina et al., 2016; Адамчук і Акульонок, 2017).

However, there is a need for further search for plant species which can provide bee families with complete protein and carbohydrates. The considered value to bees has common chicory (Cichorium intybus L.). This is a perennial plant that has a prolonged flowering period. The study of the species

\footnotetext{
*Corresponding author: Leonora Adamchuk, National University of Life and Environmental Sciences of Ukraine, Kyiv, Ukraine, $₫$ leonora.adamchuk@gmail.com
} 
composition of the bee pollen conducted in Ukraine showed that in the summer and late summer periods, the share of pollen of herbaceous plants rose sharply (including common chicory) and it was 91.3 and $93.7 \%$, respectively of the total amount of bee pollen (Stashenko, 2005).

However, the duration of flowering chicory may change according to the nature-climatic conditions. So, some scientists indicate 32 days (Мельников и Еськов, 2015). Others studies of the phenology of harvesting bee pollen of Cichorium intybus during the year showed that it continues for 99 days (Süer and Sorkun, 2006). Chicory is a source of protein feed and nectar for bees. Its honey productivity is $100 \mathrm{~kg} / \mathrm{ha}$, and honey is light, has a bluish tint and pleasant taste (Глухов, 1955). From 1 day one flower of chicory allocates $100-250 \mathrm{mg}$ of nectar, therefore this plant is recommended for use in a trophic conveyor for honey bees (Прибылова и Иванов, 2011).

The first information about using of chicory could be found in the writings of Pliny (23-79 A.D.). Avicenna (980-1037) used chicory for treating many diseases. Scientists had thoroughly studied the biochemical composition and properties of raw chicory (Deng et al., 2001; Kisiel and Zielińska, 2001; El-Lakany et al., 2004; Malarz et al., 2013; Wang et al., 2013; Aisa and Xin, 2015). They consider that the most valuable substances contained in chicory are inulin, lactucin and taraksasterol. Studies were conducted on plant cultivation, since chicory is considered highly suitable for culture introduction (Таранов, 1986). The conditions for organic production of chicory are investigated (Süer and Sorkun, 2006).

For beekeepers, this plant is valuable due to the flowering even in the cool and rainy weather, as well as the stability of stairs to frost. However, there is a need for further study of nectarous properties Cichorium, the definition of pollen productivity, the period of nectar production in Ukraine conditions for the possibility of using this plant as a source of feed for bees and obtaining qualitative commodity products in bee-farms. Therefore, the aim of research was to explore pollen and honey properties of common chicory.

\section{Material and methodology}

Scientific issues which set up during the research, have been solved experimentally, using the next methods of research: zootechnical (setting experiments, nectar, honey and pollen productivity), microscopical (nectarial and pollen productivity of enthomopile plants, analysis of pollen), micrometrical (morphological features of bee pollen, formation of pollen lump), statistical (biometrical data processing) and analytical (literature review, analysis and generalization of the results of research).

Thus, biological nectar productivity was determined by multiplying the average amount of sugar released by one inflorescence (mg), by the number of flowers per plant (pcs.) and the duration of flowering of the plant (days). The conventional technology of common chicory cultivation based on a wide-row sowing method with a width of rows of $45 \mathrm{~cm}$ and distance in the row between plants 10-12 cm. That is, 9 pcs. per 1 running meter or 27 units. per square. We derived a formula for calculating the probable honey yield of a solid mass of the plant taking into account the obtained results of nectar productivity:

$$
\frac{(B N \times N P) \times 0.5}{D F}=H P
$$


where: $\quad B N-$ biological nectar productivity of 1 plant, $\mathrm{kg} ; N P$ - number of plants per 1 ha, pcs.; 0.5 - coefficient of conversion to the actual honey stock; DF - the duration of flowering, days; HP - honey productivity, $\mathrm{kg} / \mathrm{ha}$

Experimental samples were collected in the 2016 summer period. Equipment involved in research: scales ANG 100C, microscopes Zeiss SteREO Discovery V20 and Zeiss HBO 50/AC. Online database PalDat, ChemStation databases and personal developments served as information media. Next software resources have been used: Ascension Waves vision and other specialized software, statistical programs for micrometry, graphic editor Paint.Net 4.0.

\section{Results and discussion}

We have established the flowering period of one Cichorium intybus plant in Skvyra, Baryshivka and Kyiv-Sviatoshyn districts of Kyiv region; Khmilnyk, Vinnitsia region; Stara Syniava district, Khmelnytskyi region; Myrgorod district, Poltava region; Konotop and Romny districts Sumy region; Pryluky district, Chernihiv region; Gaivoron district, Kiyrovohrad region (Table 1).

Table 1 Period of flowering of common chicory (Cichorium intybus) in some regions of Ukraine, $n=50$

\begin{tabular}{|l|c|c|c|c|}
\hline No & District & $\begin{array}{c}\text { Start of flowering } \\
\text { season, dd.mm }\end{array}$ & $\begin{array}{c}\text { End of flowering } \\
\text { season, dd.mm }\end{array}$ & $\begin{array}{c}\text { Duration, } \\
\text { days }\end{array}$ \\
\hline 1. & Skvyra district, Kyiv region & 20.06 & 10.09 & 82 \\
\hline 2. & Baryshivka district, Kyiv region & 20.06 & 12.09 & 84 \\
\hline 3. & Kyiv-Sviatoshyn district, Kyiv region & 20.06 & 10.09 & 82 \\
\hline 4. & Khmilnyk, Vinnitsia region & 20.06 & 15.09 & 87 \\
\hline 5. & Stara Syniava district, Khmelnytskyi & 22.06 & 10.09 & 80 \\
\hline 6. & Myrgogion & 15.06 & 15.09 & 92 \\
\hline 7. & Konotop district, Poltava region & 22.06 & 05.09 & 75 \\
\hline 8. & Romny district, Sumy region & 22.06 & 05.09 & 75 \\
\hline 9. & Pryluky district, Chernihiv region & 22.06 & 15.09 & 85 \\
\hline 10. & Gaivoron district, Kiyrovohrad region & 10.06 & 20.09 & 102 \\
\hline
\end{tabular}

It was found out that the largest period of flowering Cichorium intybus was in Myrgorod (92 days) and Gaivoron (102 days) districts. Thus, in Konotop and Romny districts the period of flowering was $26 \%$ shorter compared to Gaivoron. However, throughout in the Forest-Steppe zone of Ukraine, Cichorium intybus has a long flowering time compared to other plant species and averaged $84 \pm 8$ days. This gives reason to consider Cichorium intybus promising for use in beekeeping. In addition, this plant provides bees with carbohydrate and protein foods in the second half of the summer, which is very important for the formation of fodder stocks in the winter and the growth of generations of bees that will go to winter.

Nectar productivity of Cichorium intybus is determined by the amount of sugar in the nectar of flowers from one plant in $\mathrm{g}$ (Table 2). 
Table 2 Nectar productivity of common chicory (Cichorium intybus), $n=10$

\begin{tabular}{|c|c|c|c|c|c|}
\hline \multirow[t]{3}{*}{ № area } & \multicolumn{5}{|c|}{ Indicator } \\
\hline & \multicolumn{5}{|c|}{ Total sugar content in nectar } \\
\hline & $M \pm m, ~ m g$ & $\delta$ & $C v, \%$ & Min, $\mathbf{m g}$ & Max, mg \\
\hline 1. & $1.10 \pm 0.026$ & 0.084 & 7.569 & 0.951 & 1.150 \\
\hline 2. & $1.13 \pm 0.007$ & 0.022 & 1.961 & 1.087 & 1.149 \\
\hline 3. & $1.05 \pm 0.025$ & 0.078 & 7.406 & 0.952 & 1.150 \\
\hline 4. & $1.09 \pm 0.030$ & 0.094 & 8.630 & 0.951 & 1.149 \\
\hline 5. & $1.12 \pm 0.021$ & 0.067 & 5.941 & 0.956 & 1.150 \\
\hline 6. & $1.14 \pm 0.002$ & 0.005 & 0.428 & 1.135 & 1.150 \\
\hline 7. & $1.03 \pm 0.025$ & 0.080 & 7.776 & 0.954 & 1.150 \\
\hline 8. & $1.11 \pm 0.023$ & 0.071 & 6.399 & 0.953 & 1.149 \\
\hline 9. & $1.11 \pm 0.018$ & 0.056 & 5.104 & 1.003 & 1.149 \\
\hline \multirow[t]{2}{*}{10.} & $1.12 \pm 0.014$ & 0.045 & 4.031 & 1.003 & 1.150 \\
\hline & \multicolumn{5}{|c|}{ Number of flowers in the inflorescence } \\
\hline 1. & $19.4 \pm 0.60$ & 1.897 & 9.780 & 16 & 22 \\
\hline 2. & $19.4 \pm 0.43$ & 1.350 & 6.958 & 18 & 22 \\
\hline 3. & $19.0 \pm 0.54$ & 1.700 & 8.946 & 16 & 22 \\
\hline 4. & $19.0 \pm 0.45$ & 1.414 & 7.443 & 16 & 20 \\
\hline 5. & $19.2 \pm 0.53$ & 1.687 & 8.784 & 16 & 22 \\
\hline 6. & $20.2 \pm 0.47$ & 1.476 & 7.306 & 18 & 22 \\
\hline 7. & $19.2 \pm 0.61$ & 1.932 & 10.063 & 16 & 22 \\
\hline 8. & $20.0 \pm 0.30$ & 0.943 & 4.714 & 18 & 22 \\
\hline 9. & $19.4 \pm 0.52$ & 1.647 & 8.487 & 16 & 22 \\
\hline \multirow[t]{2}{*}{10.} & $19.6 \pm 0.27$ & 0.843 & 4.302 & 18 & 20 \\
\hline & \multicolumn{5}{|c|}{ Number of inflorescences per plant } \\
\hline 1. & $104.6 \pm 7.91$ & 23.916 & 23.916 & 65 & 133 \\
\hline 2. & $89.2 \pm 6.21$ & 22.018 & 22.018 & 61 & 117 \\
\hline 3. & $74.3 \pm 8.93$ & 37.989 & 37.989 & 31 & 115 \\
\hline 4. & $81.7 \pm 11.13$ & 43.082 & 43.082 & 35 & 132 \\
\hline 5. & $77.3 \pm 8.93$ & 36.529 & 36.529 & 33 & 122 \\
\hline 6. & $89.7 \pm 6.78$ & 23.888 & 23.888 & 57 & 116 \\
\hline 7. & $62.4 \pm 5.99$ & 30.333 & 30.333 & 43 & 94 \\
\hline 8. & $80.9 \pm 12.49$ & 48.809 & 48.809 & 32 & 131 \\
\hline 9. & $89.0 \pm 8.49$ & 30.159 & 30.159 & 53 & 125 \\
\hline 10. & $81.8 \pm 11.99$ & 46.340 & 46.340 & 34 & 129 \\
\hline
\end{tabular}

$M$ - arithmetic mean; $m$ - error of a measurement; $\delta$ - standard deviation; $C v$ - coefficient of variation; Max, Min - maximum, minimum value sample 
The obtained results confirm that the index of honey productivity varies from 166.59 to $301.34 \mathrm{~kg} / \mathrm{ha}$ depending on the place of germination. Significant influence on this index may be the soil, depth of groundwater, rainfall and other natural and climatic factors.

It has been established that biological pollen productivity of one Cichorium intybus plant was ranging 1.785 to $3.064 \mathrm{~g}$. Assuming that bees gather $50 \%$ of pollen, it is possible to collect from 89.25 to $153.29 \mathrm{~g}$ of pollen from 100 of plants. Apart from that, it is also possible to trace the dependency between honey productivity and pollen productivity of the plant. Thus, the highest recoreded value of these variables was observed in Skvyra district, Kyiv region and the lowest - in Konotop district, Sumy region.

Pollen grains of Cichorium intybus were also researched in honeys of different plants origin. It has been established that in coriander honey the pollen of this plant is ranging from 1 to 5\%; summer herbage honey - from 8 to 20\%; buckwheat honey - from 2 to $8 \%$; sunflower honey - from 1 to $4 \%$; tilia honey - from 1 to $3 \%$; late-summer herbage honey - from 18 to $27 \%$ of pollen grains. This fact proves that bees willingly use Cichorium intybus during all of the active season.

Calculations of the productivity of Cichorium intybus in various regions of the Forest-Steppe zone of Ukraine are presented in Table 3.

Table 3 Honey and pollen productivity of common chicory (Cichorium intybus), $n=10$

\begin{tabular}{|c|c|c|c|c|c|c|c|}
\hline \multirow{2}{*}{ 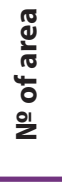 } & \multirow[t]{2}{*}{ BNP, $g$} & \multirow{2}{*}{$\begin{array}{c}\text { HP, } \\
\text { kg/ha }\end{array}$} & \multicolumn{3}{|c|}{ Quantity indicator, $M \pm m$} & \multicolumn{2}{|c|}{ Averaged indicator } \\
\hline & & & $\begin{array}{l}\text { pollen in the } \\
\text { flower, } \mathrm{mg}\end{array}$ & $\begin{array}{c}\text { number of } \\
\text { flowers in } \\
\text { inflorescence }\end{array}$ & $\begin{array}{c}\text { number of } \\
\text { inflorescences } \\
\text { on the plant }\end{array}$ & $\begin{array}{c}\text { pollen in } \\
\text { inflorescence, } \\
\text { mg }\end{array}$ & BPP, $\mathbf{g}$ \\
\hline 1. & 183.04 & 301.34 & $1.51 \pm 0.041$ & $19.4 \pm 0.60$ & $104.6 \pm 7.91$ & 29.294 & 3.064 \\
\hline 2. & 164.26 & 263.98 & $1.49 \pm 0.053$ & $19.4 \pm 0.43$ & $89.2 \pm 6.21$ & 28.906 & 2.578 \\
\hline 3. & 121.55 & 200.11 & $1.53 \pm 0.052$ & $19.0 \pm 0.54$ & $74.3 \pm 8.93$ & 29.070 & 2.159 \\
\hline 4. & 147.20 & 228.42 & $1.48 \pm 0.050$ & $19.0 \pm 0.45$ & $81.7 \pm 11.13$ & 28.120 & 2.297 \\
\hline 5. & 132.98 & 224.40 & $1.50 \pm 0.028$ & $19.2 \pm 0.53$ & $77.3 \pm 8.93$ & 28.800 & 2.226 \\
\hline 6. & 190.04 & 278.86 & $1.41 \pm 0.026$ & $20.2 \pm 0.47$ & $89.7 \pm 6.78$ & 28.482 & 2.554 \\
\hline 7. & 92.55 & 166.59 & $1.49 \pm 0.043$ & $19.2 \pm 0.61$ & $62.4 \pm 5.99$ & 28.608 & 1.785 \\
\hline 8. & 134.70 & 242.46 & $1.56 \pm 0.043$ & $20.0 \pm 0.30$ & $80.9 \pm 12.49$ & 31.200 & 2.524 \\
\hline 9. & 162.90 & 258.73 & $1.46 \pm 0.056$ & $19.4 \pm 0.52$ & $89.0 \pm 8.49$ & 28.324 & 2.520 \\
\hline 10. & 183.16 & 242.42 & $1.49 \pm 0.035$ & $19.6 \pm 0.27$ & $81.8 \pm 11.99$ & 29.204 & 2.388 \\
\hline
\end{tabular}

BNP - biological nectar productivity of one plant; HP - honey productivity; BPP - biological pollen productivity; $\mathrm{M}$ - arithmetic mean; $\mathrm{m}$ - error of a measurement

The appearance of the pollen of Cichorium intybus in the late-summer heritage honey proves the significant value of this plant in providing of carbohydrid feed for bees. It is $22.8 \pm 1.53 \%$. The bee pollen from local apiaries during the flowering of Cichorium intybus has been analyzed. It has been established that from 63 of studied samples of bee pollen 37 contained pollen lumps formed from C. intybus by bees. 10 of them contained Cichorium intybus bee pollen ranging from 10 to $80 \%$, the others - less than $10 \%$. 
Most of the pollen lumps of Cichorium intybus had a shaping level of 4 points (Table 4). Bee pollen was not an identical form, flattened sides. It was established that the weight of one pollen lump was in the range from 2.8 to $12.2 \mathrm{mg}$.

Table 4 Morphological characteristics of bee pollen lump of Cichorium intybus, $n=50$

\begin{tabular}{|l|c|c|c|c|c|}
\hline Indicator & $\mathbf{M} \pm \mathbf{m}$ & $\mathbf{C v}(\%)$ & $\delta$ & Max & Min \\
\hline Weight, $\mathbf{m g}$ & $7.21 \pm 0.255$ & 25.047 & 1.806 & 42.2 & 2.8 \\
\hline Length, mm & $3.42 \pm 0.048$ & 7.735 & 0.264 & 3.74 & 2.82 \\
\hline Width, mm & $2.97 \pm 0.070$ & 12.988 & 0.386 & 5 & 3 \\
\hline Shaping level, point & $4 \pm 0.15$ & 20.761 & 0.830 & 5 & 3 \\
\hline
\end{tabular}

$\mathrm{M}$ - arithmetic mean; $\mathrm{m}$ - error of a measurement; Cv - coefficient of variation; $\delta$ - standard deviation; Max, Min - maximum, minimum value sample.

It was found that the variation in the length of the pollen lump was weak (7.74\%), in contrast to other indicators. The sharping level of pollen lump (4 points) allows us to assume the possibility of using this plant to obtain commercial bee pollen.

\section{Conclusions}

It was established a long flowering period of common chicory in the range from 75 to 102 days. Plant productivity indicators for honey bees were established: biological nectar productivity was in the range from 92.55 to $190,04 \mathrm{~g}$ from one common chicory plant; honey productivity was in the range from 166.59 to $301.34 \mathrm{~kg} / \mathrm{ha}$; the biological pollen was in the range from 1,785 to 3,064 g. As a result of pollen analysis of polyfloral honey obtained during the summer of 2016 the pollen grains of common chicory were found in the range from 1 to $27 \%$. Pollen lumps of common chicory in the range from 10 to $80 \%$ of the total fee were in polyfloral bee pollen collected during the summer of 2016. The morphometric parameters of the bee pollen were ascertained: the sharping level of the pollen lump was $4 \pm 0.15$ points, the weight of one pollen lump was $7.21 \pm 0.255 \mathrm{mg}$, the length of one pollen lump was $3.42 \pm 0.048 \mathrm{~mm}$, the width of one pollen lump was $2.97 \pm 0.070 \mathrm{~mm}$.

\section{Acknowledgments}

The publication was prepared with the active participation of researchers involved in the International network AgroBioNet of the Institutions and researchers for realization of research, education and development program «Agrobiodiversity for improving nutrition, health and life quality» TRIVE (ITMS 26110230085) and within the project ITEBIO (ITMS 26220220115). Co-author Leonora Adamchuk thanks to the International Visegrad Fund for scholarship and research internships, during which were got the results and knowledge presented in this paper.

\section{References}

Aisa, H.A., Xin, X. 2015. Cichorium glandulosum Bioss. et Huet (Juju, Chicory). Dietary Chinese Herbs, p. 711-720. DOI: 10.1007/978-3-211-99448-1_80

Brindza, J., Schubertova, Z., Brovarskyi, V., Motyleva, S., Mertvischeva, M., Grygorieva, O. 2015. Morphological characteristics of common buckwheat (Fagopyrum esculentum Moench) pollen grains and bee pollen. Науковий вісник НУБіП України. Серія Технологія виробництва і переробки продукції тваринництва, Вип. 223, с. 17-24. http://nbuv.gov.ua/UJRN/nvnau_tevppt_2015_223_4 
Brovarskij, V., Brindza, J. a i. 2010. Včelí obnôžkový pel.' Vydavatel' - FOP IS, Maidachenko.

Deng, Y. Scott, L., Swanson, D., Snyder, J. K., Sari, N., Dogan H. 2001. Guaianolide sesquiterpene lactones from Cichorium intybus (Asteraceae). Naturforsch, vol. 56b, p. 787-796. DOI: 10.1002/chin.200203022.

El-Lakany, A.M., Aboul-Ela, M.A., Abdul-Chani, M.M., Mekky, H. 2004. Chemical constituents and biological activities of Cichorium intybus L. Nat Prod Sci, no 10(2), p. 69-73.

Grygorieva, O., Nikolaieva, N., Brindza, J., Klymenko, S. 2015. Pollen and bee pollen features of sweet chestnut (Castanea sativa Mill.). Науковий вісник НУБіП України. Серія Технологія виробництва і переробки продукції тваринництва, вип. 223, с. 35-40. http://nbuv.gov.ua/UJRN/nvnau_tevppt_2015_223_6

Kisiel, W., Zielińska, K. 2001. Guaianolides from Cichorium intybus and structure revision of Cichorium sesquiterpene lactones. Phytochemistry, no. 57, p. 523-527. https://www.ncbi.nlm.nih.gov/ pubmed/11394851

Malarz, J., Stojakowska, A., Szneler, E., Kisiel, W. 2013. A new neolignan glucoside from hairy roots of Cichorium intybus: a review. Phytochem Lett, vol. 6, p. 59-61. DOI: 10.1016/j.phytol.2012.10.011

Redina, N.M., Adamchuk, L.O., Nikolaieva, N.V., Brindza, J. 2016. Morphological characteristics of bee pollen obtained from Brassica napus L. Науковий вісник Львівського національного університету ветеринарної медицини та біотехнологій імені СЗ Ґжицького, т. 18, № 2-3, (68), с. 73-78. https:// nvlvet.com.ua/index.php/journal/article/view/728/727

Süer, B., Sorkun, K. 2006. A phenological calendar of pollens collected by Apis mellifera L.: a review. Academic Journal, vol. 6(10-12), p. 12.

Wang, Q., Liu, Y., Chen, G., Cui, J. 2013. Antimicrobial and antioxidant activities of Cichorium intybus root extract using orthogonal matrix design: a review. J Food Sci, vol. 78(2), p. 258-263.

Адамчук, Л.О., Акульонок, О.І. 2017. Морфологічні особливості бджолиного обніжжя з Salix L. Науковий вісник НУБіП України. Серія: Технологія виробництва і переробки продукції тваринництва, вип. 250, c. 105-113. http://nbuv.gov.ua/UJRN/nvnau_tevppt_2016_250_15

Адамчук, Л.О., Броварський, В.Д., Новицька, А.Т., Білоцерківець, Т.І. 2016. Cichorium L. Для забезпечення бджіл кормами. Науково-технічний бюлетень, вип. 116, с. 5-15. http://nbuv.gov.ua/ UJRN/Ntb_2016_116_4

Боярчук, С.В. 2015. Оптимізація забезпечення кормами бджолиних сімей. Науковий вісник НУБіП України, №. 223, с. 57-64.

Глухов, М. М. 1955. Медоносные растения. Издание - Москва, Сельгосиздат, 512 с.

Люльчак, О.А., Адамчук, Л.О. 2016. Біорізноманіття пилконосних рослин. Збірник праць за підсумками VI Міжнародної науково-практичної конференції вчених, аспірантів і студентів, с. 135-137.

Максимов, А.С., Максимов, С.П., Лимбунов, С.Г. 2014. Медоносные ресурсы ы качество меда степной и лесостепной зон Республики Бурятия. Весник Бурятской государственной сельскохазяйственной академии имени В. Р. Филипова, ч. 2 (35), с. 128-131.

Мельников, А.В., Еськов, И.Д. 2015. Последовательность цветения нектароносных и пыльценосных растений в западной микрозоне Саратовской области. Сборник статей международной научно-практической конференции посвященной 128-й годовщине со дня рождения академика Н. И. Вавилова: Вавиловские чтения, с. 270.

Прибылова, Е.П., Иванов, Е.С. 2011. Оценка нектаропродуктивности видов растений и травянистых экосистем Рязянской области. Вестник Российского университета дружбы народов, ч. 2, с. 16-21.

Рожков, К.А., Токар, А.І. 2014. Качество естественных кормов медоносных пчел в условиях Лененградской области. Вестник Новгородского государственного университета им. Ярослава Мудрого, ч. 76, с. 34-38.

Сташенко, B.І. 2005. Флороміграція бджіл та хімічний склад бджолиного обніжжя в умовах Лісостепу України: автореф. дис. на здоб. наук. ст. канд. с.-г. наук: спец. 06.02 .04 «Технологія виробництва продукції тваринництва». Київ: НАУ, 23 с.

Таранов, Г.Ф. 1986. Корма и кормление пчел. Издательство - Москва, Россельсхозиздат, 160 с. 